\title{
SEISMIC POUNDING BETWEEN ADJACENT BUILDING STRUCTURES SUBJECTED TO NEAR FIELD GROUND MOTION
}

\author{
Chetan J. Chitte' ${ }^{1}$, Anand S. Jadhav², Hemraj R. Kumavat ${ }^{3}$ \\ ${ }^{1}$ Assistant Professor, Dept. of Civil Engg. RCPIT, Shirpur, Maharashtra, India \\ ${ }^{2}$ Assistant Professor, Dept. of Civil Engg. JIT, Nashik, Maharashtra, India \\ ${ }^{3}$ Assistant Professor, Dept. of Civil Engg. RCPIT, Shirpur, Maharashtra, India
}

\begin{abstract}
The pounding of adjacent structures during earthquakes has been receiving considerable attention in recent years. This is because adjacent structures with inadequate clear spacing between them have suffered considerable structural and nonstructural damage as a result of their collision during major earthquakes. The different dynamic characteristics of adjacent buildings make them vibrate out of phase, and pounding occurs if there is a lack of sufficient space between them. Pounding between closely spaced building structures can be a serious hazard in seismically active areas. Past seismic codes did not give definite guidelines to preclude pounding, because of this and due to economic considerations including maximum land usage requirements, especially in the high density populated areas of cities, there are many buildings worldwide which are already built in contact or extremely close to another that could suffer pounding damage in future earthquakes. The highly congested building system in many metropolitan cities constitutes a major concern for seismic pounding damage.
\end{abstract}

Keywords: Pounding, Major earthquakes, Dynamic characteristics.

\section{INTRODUCTION}

Building structures are often built close to each other as in the case of residential building complexes or in downtown of metropolitan cities where the cost of land is high. Due to the close proximity of these structures, they have often been found to impact each other while responding to earthquake induced strong ground motion. An earthquake can cause sudden movement of the ground that is transferred to the structure through foundation. The ground motion during an earthquake is usually defined by a time history of the ground acceleration and can be obtained in three directions by instruments known as strong-motion acceleographs. Evaluating the response of a building structure subjected to earthquake ground motion is a dynamic problem where at any instant, the internal resisting forces of the structure are in equilibrium with the time varying inertia force that is defined as the product of the structural mass and the instantaneous ground acceleration.

\subsection{Objective of Study}

The main objective and scope are to evaluate the Development of an analytical model and methodology for the formulation of the adjacent building-pounding problem based on the available theories, and carry out parametric study to identify the most important parameters. To compare potential Pounding under Far field and near field ground motions and propose minimum seismic gap between buildings under both far field and near field ground motion conditions.

For the purpose of this study, SAP2000 software has been chosen, a linear and non-linear static and dynamic analysis and design program for three dimensional structures. The application has many features for solving a wide range of problems from simple 2-D trusses to complex 3-D structures.

\section{SEISMIC POUNDING EFFECT BETWEEN}

\section{ADJACENT BUILDINGS}

Seismic pounding is one of the main causes of severe building damages in earthquake .The non-structural damage involves pounding or movement across separation joints between adjacent structures.

A separation joint is the distance between two different building structures - often two wings of the same facility that allows the structures to move independently of one another.

A seismic gap is a separation joint provided to accommodate relative lateral movement during an earthquake. In order to provide functional continuity between separate wings, building utilities must often extend across these building separations, and architectural finishes must be detailed to terminate on either side. The separation joint may be only an inch or two in older constructions or as much as a foot in some newer buildings, depending on the expected horizontal movement, or seismic drift.

Structural poundings happen because of swaying of adjacent buildings with different mode shapes and periods under seismic loads which are not separated from each other properly (Fig.1). During earthquakes, structure's mass and rigidity affect seismic behaviour. It is nearly impossible to 
construct a building which has similar seismic behaviour to another building.

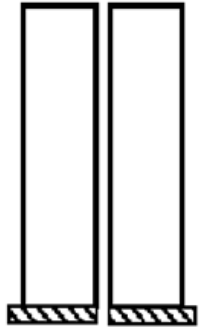

(a)

Before

Earthquake

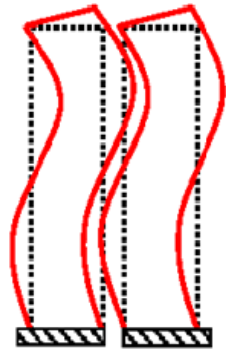

(b)

Similar Seismi Behavior

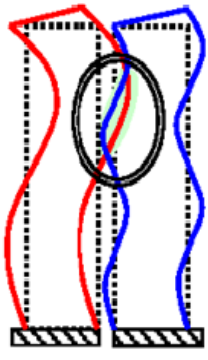

(c)

Different Seismic Behavior
Fig -1: Seismic behaviour of adjacent buildings

\section{NEAR SOURCE AND FAR SOURCE GROUND}

\section{MOTION}

The characteristic of strong motion in the vicinity of causative fault (near field) is strongly dependent on the nature of faulting. The motion depends on source parameters such as fault shape, its area, maximum fault dislocation, complexity of slipping process, stress drop and the distance of fault plane from the ground surface. The closer a site is to the epicenter, the stronger the ground motion, and vice versa.

\subsection{Ground Motions used in Study}

Time history in $\mathrm{x}$-direction using three near source and three far source earthquake is performed in all the models using the computer program SAP2000 (CSI 2014). Each case is analyzed for three near source and three far source earthquakes as given in Table 1 and Table 2.

Table 1: Near Source Earthquake's used in study

\begin{tabular}{|l|l|l|l|l|l|l|}
\hline $\begin{array}{l}\text { Sr. } \\
\text { N } \\
\text { o. }\end{array}$ & Earthquake & $\begin{array}{l}\text { M } \\
\text { W }\end{array}$ & $\begin{array}{l}\text { Statio } \\
\mathrm{n}\end{array}$ & $\begin{array}{l}\text { PGA } \\
(\mathrm{g})\end{array}$ & $\begin{array}{l}\text { Closet } \\
\text { Distan } \\
\text { ce }\end{array}$ & Tg \\
\hline 1 & $\begin{array}{l}\text { Northridge,Sy } \\
\text { mlar } \\
\text { County }\end{array}$ & $\begin{array}{l}6.6 \\
9\end{array}$ & $\begin{array}{l}\text { Sylma } \\
\mathrm{r} \\
\text { Statio } \\
\mathrm{n}\end{array}$ & $\begin{array}{l}0.71 \\
23\end{array}$ & 5.35 & 40 \\
\hline 2 & $\begin{array}{l}\text { Cape } \\
\text { Mendacino }\end{array}$ & $\begin{array}{l}7.0 \\
1\end{array}$ & $\begin{array}{l}\text { Petrol } \\
\text { ia }\end{array}$ & $\begin{array}{l}0.62 \\
36\end{array}$ & 8.18 & 36 \\
\hline 3 & $\begin{array}{l}\text { Landers } \\
\text { Lucrene }\end{array}$ & $\begin{array}{l}7.2 \\
8\end{array}$ & $\begin{array}{l}\text { Lucer } \\
\text { ne }\end{array}$ & $\begin{array}{l}0.72 \\
14\end{array}$ & 2.19 & 48.1 \\
& & \multicolumn{2}{|l}{} & 2 \\
\hline
\end{tabular}

$\mathrm{M}_{\mathrm{w}}$-Moment Magnitude,

PGA-Peak Ground Acceleration

Tg-Characteristic Period of ground motion record
Table 2: Far Source Earthquake's used in study

\begin{tabular}{|l|l|l|l|l|l|l|}
\hline $\begin{array}{l}\text { Sr. } \\
\text { No }\end{array}$ & $\begin{array}{l}\text { Earthqua } \\
\text { ke }\end{array}$ & $\begin{array}{l}\text { M } \\
\text { W }\end{array}$ & Station & $\begin{array}{l}\text { PGA } \\
(\mathrm{g})\end{array}$ & $\begin{array}{l}\text { Closet } \\
\text { Distan } \\
\text { ce }\end{array}$ & Tg \\
\hline 4. & $\begin{array}{l}\text { Imperial } \\
\text { Valley }\end{array}$ & $\begin{array}{l}6.5 \\
3\end{array}$ & $\begin{array}{l}\text { USGS } \\
5066 \\
\text { Coachell } \\
\text { a Canal } \\
\text { \#4 }\end{array}$ & $\begin{array}{l}0.122 \\
0\end{array}$ & 83.94 & $\begin{array}{l}28.5 \\
3\end{array}$ \\
\hline 5. & $\begin{array}{l}\text { Palm } \\
\text { Spring }\end{array}$ & $\begin{array}{l}6.0 \\
6\end{array}$ & $\begin{array}{l}\text { Anza } \\
\text { Red } \\
\text { Mountai } \\
\mathrm{n}\end{array}$ & $\begin{array}{l}0.121 \\
4\end{array}$ & 46.17 & 11 \\
\hline 6. & $\begin{array}{l}\text { Loma } \\
\text { Prieta }\end{array}$ & $\begin{array}{l}6.9 \\
3\end{array}$ & $\begin{array}{l}\text { Belmont } \\
- \\
\text { Envirote } \\
\text { ch }\end{array}$ & $\begin{array}{l}0.118 \\
5\end{array}$ & 64.55 & 39.9 \\
\end{tabular}

\section{MODELLING APPROACH OF BUILDINGS}

Three different models have been considered for the purpose of study. The flow chart given in Fig 2 shows the group of example structures studied for pounding analysis.

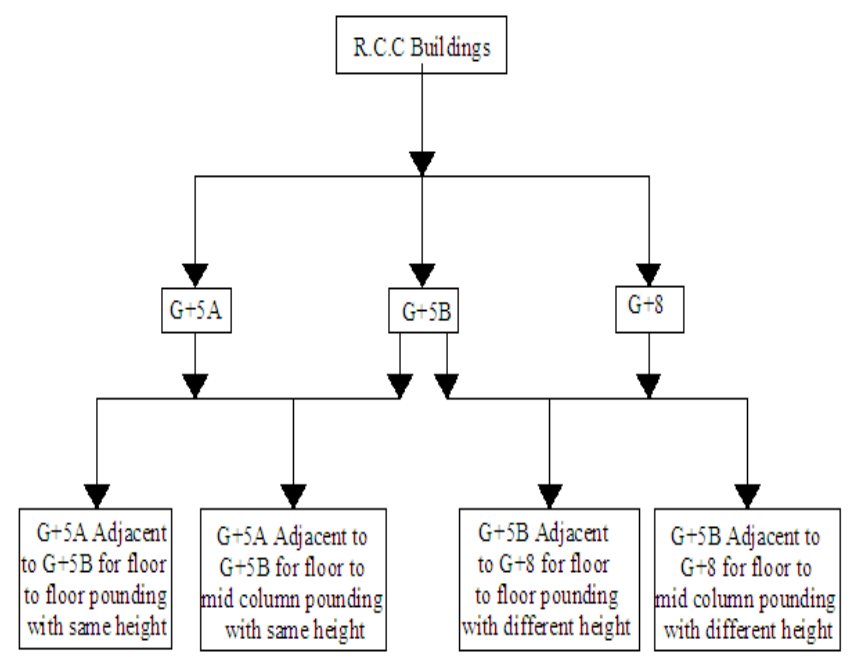

Fig -2: Examples of Structures studied for Pounding Analysis

\subsection{Properties of Building Structures considered for pounding Analysis}

\subsubsection{G+5A Building}

The R.C.C buildings used in this study is $(\mathrm{G}+5)$. The Bay width of $2 \mathrm{D}$ plane frame is $2-4 \mathrm{~m}$ bays along longitudinal direction (X-direction). The story height is $3.0 \mathrm{~m}$ for all the stories. The live load is taken as $1.5 \mathrm{KN} / \mathrm{m}^{2}$ on roof and 3 $\mathrm{KN} / \mathrm{m}^{2}$ on all other floors while the floor finish load is taken as $1 \mathrm{KN} / \mathrm{m}^{2}$ on roof and $1.5 \mathrm{KN} / \mathrm{m}^{2}$ on all other floors. The Terrace Water Proofing is $1.5 \mathrm{KN} / \mathrm{m}^{2}$ Thickness of brick wall over all floor beams except over roof slab is taken as $230 \mathrm{~mm}$, while thickness of parapet is considered as $0.23 \mathrm{~m}$. Height of parapet wall is assumed as $1 \mathrm{~m}$. Thickness of slab 
is taken as $100 \mathrm{~mm}$. The unit weight of reinforced concrete and brick masonry is taken as $25 \mathrm{KN} / \mathrm{m}^{3}$ and $20 \mathrm{KN} / \mathrm{m}^{3}$ respectively. The compressive strength of concrete is 20 $\mathrm{N} / \mathrm{mm}^{2}$ and yield strength of steel reinforcement is 415 $\mathrm{N} / \mathrm{mm}^{2}$. The modulus of elasticity of concrete and steel are $22360.6 \mathrm{~N} / \mathrm{mm}^{2}$ and $2 \times 10^{5} \mathrm{~N} / \mathrm{mm}^{2}$ respectively.

\subsubsection{G+5B Building}

The R.C.C buildings used in this study is $(\mathrm{G}+5)$. The Bay width of $2 \mathrm{D}$ plane frame is $2-4 \mathrm{~m}$ bays along longitudinal direction (X- direction). The story height is $3.0 \mathrm{~m}$ for all the stories. The live load is taken as $2 \mathrm{KN} / \mathrm{m}^{2}$ on roof and 3 $\mathrm{KN} / \mathrm{m}^{2}$ on all other floors while the floor finish load is taken as $1 \mathrm{KN} / \mathrm{m}^{2}$ on roof and $1 \mathrm{KN} / \mathrm{m}^{2}$ on all other floors. The Terrace Water Proofing is $1.5 \mathrm{KN} / \mathrm{m}^{2}$ Thickness of brick wall over all floor beams except over roof slab is taken as $230 \mathrm{~mm}$, while thickness of parapet is considered as 0.23 $\mathrm{mm}$. Height of parapet wall is assumed as $1 \mathrm{~m}$. Thickness of slab is taken as $150 \mathrm{~mm}$. The unit weight of reinforced concrete and brick masonry is taken as $25 \mathrm{KN} / \mathrm{m}^{3}$ and 20 $\mathrm{KN} / \mathrm{m}^{3}$ respectively. The compressive strength of concrete is $20 \mathrm{~N} / \mathrm{mm}^{2}$ and yield strength of steel reinforcement is 415 $\mathrm{N} / \mathrm{mm}^{2}$. The modulus of elasticity of concrete and steel are $25000 \mathrm{~N} / \mathrm{mm}^{2}$ and $2 \times 10^{5} \mathrm{~N} / \mathrm{mm}^{2}$ respectively.

\subsubsection{G+8 Building}

The R.C.C buildings used in this study is $(\mathrm{G}+8)$. The Bay width of $2 \mathrm{D}$ plane frame is $2-4 \mathrm{~m}$ bays along longitudinal direction (X-direction). The story height is $3.0 \mathrm{~m}$ for all the stories. The live load is taken as $1.5 \mathrm{KN} / \mathrm{m}^{2}$ on roof and 3 $\mathrm{KN} / \mathrm{m}^{2}$ on all other floors while the floor finish load is taken as $1 \mathrm{KN} / \mathrm{m}^{2}$ on roof and $1 \mathrm{KN} / \mathrm{m}^{2}$ on all other floors. The Terrace Water Proofing is $1.5 \mathrm{KN} / \mathrm{m}^{2}$ Thickness of brick wall over all floor beams except over roof slab is taken as $230 \mathrm{~mm}$, while thickness of parapet is considered as 0.23 $\mathrm{mm}$. Height of parapet wall is assumed as $1 \mathrm{~m}$. Thickness of slab is taken as $100 \mathrm{~mm}$.. The unit weight of reinforced concrete and brick masonry is taken as $25 \mathrm{KN} / \mathrm{m}^{3}$ and 20 $\mathrm{KN} / \mathrm{m}^{3}$ respectively. The compressive strength of concrete is $25 \mathrm{~N} / \mathrm{mm}^{2}$ and yield strength of steel reinforcement is 415 $\mathrm{N} / \mathrm{mm}^{2}$. The modulus of elasticity of concrete and steel are $22360.6 \mathrm{~N} / \mathrm{mm}^{2}$ and $2 \times 10^{5} \mathrm{~N} / \mathrm{mm}^{2}$ respectively.

Table 3: Cross-section properties of Beams and Columns for $\mathrm{G}+5 \mathrm{~A}, \mathrm{G}+5 \mathrm{~B} \& \mathrm{G}+8$ Building

\begin{tabular}{|c|c|c|c|c|c|c|}
\hline $\mathrm{SCHF}$ & JLE OF I & C.C BI & MS & D CO & MNS & \\
\hline & BEAM & & & COLUI & & \\
\hline $\begin{array}{l}\text { Floor } \\
\text { Level }\end{array}$ & $\begin{array}{l}\text { Beam } \\
\text { Size }\end{array}$ & $\begin{array}{l}\text { Reinf } \\
\text { orcem } \\
\text { ent }\end{array}$ & Extra & $\begin{array}{l}\text { Colum } \\
\text { n Size }\end{array}$ & $\begin{array}{l}\text { Mai } \\
\mathrm{n} \\
\text { Steel }\end{array}$ & Ties \\
\hline & $(\mathrm{mm})$ & Bars & & $(\mathrm{mm})$ & $\begin{array}{l}(\mathrm{mm} \\
)\end{array}$ & \\
\hline Buildin & $\mathrm{G}+5 \mathrm{~A}$ & & & & & \\
\hline $\begin{array}{l}\text { Groun } \\
\mathrm{d}, 1\end{array}$ & $230 \times 450$ & $\begin{array}{l}5- \\
\text { TOR2 } \\
0\end{array}$ & $\begin{array}{l}2- \\
\text { TOR2 } \\
0\end{array}$ & $\begin{array}{l}500 \times 5 \\
00\end{array}$ & $\begin{array}{l}16 \# 1 \\
6\end{array}$ & $\begin{array}{l}\# 6 @ 15 \\
0\end{array}$ \\
\hline $2,3,4$ & $230 \times 450$ & $\begin{array}{l}5- \\
\text { TOR2 }\end{array}$ & $\begin{array}{l}2- \\
\text { TOR2 }\end{array}$ & $\begin{array}{l}450 \times 4 \\
50\end{array}$ & $\begin{array}{l}14 \# 1 \\
6\end{array}$ & $\begin{array}{l}\text { \#6@15 } \\
0\end{array}$ \\
\hline
\end{tabular}

\begin{tabular}{|c|c|c|c|c|c|c|}
\hline & & 0 & 0 & & & \\
\hline 5 & $230 \times 450$ & $\begin{array}{l}5- \\
\text { TOR2 } \\
0\end{array}$ & $\begin{array}{l}2- \\
\text { TOR2 } \\
0\end{array}$ & $\begin{array}{l}400 \times 4 \\
00\end{array}$ & $\begin{array}{l}12 \# 1 \\
6\end{array}$ & $\begin{array}{l}\# 6 @ 15 \\
0\end{array}$ \\
\hline \multicolumn{7}{|c|}{ Building G+5B } \\
\hline $\begin{array}{l}\text { Groun } \\
\mathrm{d}, 1,2, \\
3,4,5\end{array}$ & $300 \times 450$ & $\begin{array}{l}5- \\
\text { TOR2 } \\
0\end{array}$ & $\begin{array}{l}2- \\
\text { TOR2 } \\
0\end{array}$ & $\begin{array}{l}500 \times 5 \\
00\end{array}$ & $\begin{array}{l}16 \# 1 \\
6\end{array}$ & $\begin{array}{l}\# 6 @ 15 \\
0\end{array}$ \\
\hline \multicolumn{7}{|c|}{ Building $\mathrm{G}+8$} \\
\hline $\begin{array}{l}\text { Groun } \\
\mathrm{d}, 1\end{array}$ & $230 \times 450$ & $\begin{array}{l}5- \\
\text { TOR2 } \\
0\end{array}$ & $\begin{array}{l}2- \\
\text { TOR2 } \\
0\end{array}$ & $\begin{array}{l}500 \times 5 \\
00\end{array}$ & $\begin{array}{l}16 \# 1 \\
6\end{array}$ & $\begin{array}{l}\# 6 @ 15 \\
0\end{array}$ \\
\hline $2,3,4$ & $230 \times 450$ & $\begin{array}{l}5- \\
\text { TOR2 } \\
0\end{array}$ & $\begin{array}{l}2- \\
\text { TOR2 } \\
0\end{array}$ & $\begin{array}{l}450 \times 4 \\
50\end{array}$ & $\begin{array}{l}14 \# 1 \\
6\end{array}$ & $\begin{array}{l}\# 6 @ 15 \\
0\end{array}$ \\
\hline $5,6,7$ & $230 \times 450$ & $\begin{array}{l}5- \\
\text { TOR2 } \\
0\end{array}$ & $\begin{array}{l}2- \\
\text { TOR2 } \\
0\end{array}$ & $\begin{array}{l}400 \times 4 \\
00\end{array}$ & $\begin{array}{l}12 \# 1 \\
6\end{array}$ & $\begin{array}{l}\# 6 @ 15 \\
0\end{array}$ \\
\hline 8 & $230 \times 450$ & $\begin{array}{l}5- \\
\text { TOR2 } \\
0 \\
\end{array}$ & $\begin{array}{l}2- \\
\text { TOR2 } \\
0\end{array}$ & $\begin{array}{l}350 \times 3 \\
50\end{array}$ & $\begin{array}{l}10 \# 1 \\
6\end{array}$ & $\begin{array}{l}\# 6 @ 15 \\
0\end{array}$ \\
\hline
\end{tabular}

All the above mentioned building frames are designed as per requirement of IS 456 and IS 1893 . The required material properties like mass, weight density, modulus of elasticity, shear modulus and design values of the material used can be modified as per requirements or default values can be accepted. Beams and column members have been defined as 'frame elements' with the appropriate dimensions and reinforcement. Soil structure interaction has not been considered and the columns have been restrained in all six degrees of freedom at the base. Slabs have been modelled as rigid diaphragms.

Time period of the buildings is as shown in Table 4:

Table 4: Time period of the Buildings

\begin{tabular}{|l|l|l|}
\hline Buildings & Mode & Time Period \\
\hline \multirow{4}{*}{ G+5A } & 1 & 0.95 \\
\cline { 2 - 3 } & 2 & 0.30 \\
\cline { 2 - 3 } & 3 & 0.16 \\
\hline \multirow{3}{*}{$+\mathbf{5 B}$} & 1 & 0.80 \\
\cline { 2 - 3 } & 2 & 0.25 \\
\cline { 2 - 3 } & 3 & 0.13 \\
\hline \multirow{3}{*}{$\mathbf{+ 8}$} & 1 & 1.57 \\
\cline { 2 - 3 } & 2 & 0.52 \\
\cline { 2 - 3 } & 3 & 0.29 \\
\hline
\end{tabular}

\subsubsection{Assigning Loads}

Gravity loads on the structure include the self weight of beams, columns, slabs, walls and other permanent members. The self weight of beams and columns (frame members) is automatically considered by the program itself. The wall loads have been calculated and assigned as uniformly distributed loads on the beams. 
Wall load = unit weight of brickwork $\mathrm{x}$ thickness of wall $\mathrm{x}$ height of wall.

Unit weight of brickwork $=20 \mathrm{KN} / \mathrm{m}^{3}$

Thickness of wall $=0.23 \mathrm{~m}$

Wall load on roof level $=20 \times 0.23 \times 1=4.60 \mathrm{KN} / \mathrm{m}$ (parapet wall height $=1 \mathrm{~m}$ )

Wall load on all other levels $=20 \times 0.23 \times(3-0.5)=$ $11.50 \mathrm{KN} / \mathrm{m}$ (wall height $=3 \mathrm{~m})$

Live loads have been assigned as uniform area loads on the slab elements as per Table 8 (Clause 7.3.1) of IS 1893 (Part 1):2002.

Since the live load class is up to $3 \mathrm{KN} / \mathrm{m}^{2}, 25 \%$ of the imposed load has been considered Seismic weight calculation as per Table 8, (Clause 7.3.1) of IS 1893 (Part 1):2002.

\subsubsection{Type of Impact}

Two types of impact are seen in recent earthquakes can be categorized in two main groups.

A) Impact of One Floor of building with adjacent one: Since adjacent buildings may differ in the structural system of floors and/or in their applications, they have different masses, this can cause different phase oscillations.

B) Impact of Structure on the column of adjacent building: This type of impact occurs in some adjacent buildings in which floor levels are not in the same heights. Therefore, when shaking with different phase occurs, the floor of one building hits the column of another and causes serious damages which can lead to the fracture of the columns of the story. This type is the most dangerous impact that can result in sudden destruction of structure.

In present study, Group A i.e. Impact of One Floor of building with adjacent one is been considered.

Impact of One Floor of building with adjacent one is further categorized in following groups.

a) Floor to Floor Pounding with same height

i) $G+5 A$ adjacent to $G+5 B$

b) Floor to Floor Pounding with different height

i) $\mathrm{G}+8$ adjacent to $\mathrm{G}+5 \mathrm{~B}$

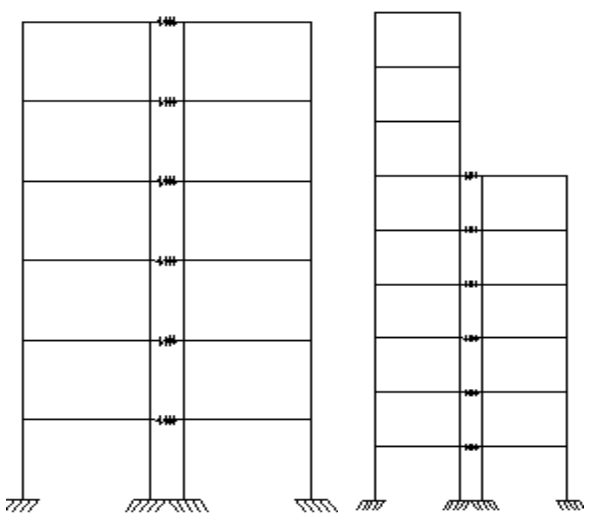

Fig- 3(a) G+5A adjacent Fig-3 (b) G+8 adjacent to G+5B to $\mathrm{G}+5 \mathrm{~B}$

\subsubsection{Time History Analysis of Building Structures:}

In order to examine the exact nonlinear behaviour of building structures, nonlinear time history analysis has to be carried out. In this method, the structure is subjected to real ground motion records. This makes this analysis method quite different from all of the other approximate analysis methods as the inertial forces are directly determined from these ground motions and the responses of the building either in deformations or in forces are calculated as a function of time, considering the dynamic properties of the building structure.

Time History analysis has been carried out using suite of three Near source and three Far source earthquake records are used in parametric study. Newmark's direct integration method has been adopted and the mass and stiffness proportional coefficients have been calculated taking into account the frequency of the structure in two consecutive modes in the same direction.

Mass proportional coefficient, $\mathrm{a}_{0=} \xi\left(2 \omega_{\mathrm{i}} \omega_{\mathrm{j}} / \omega_{\mathrm{i}}-\omega_{\mathrm{j}}\right)$ Stiffness proportional coefficient, $\mathrm{a}_{1=} \xi\left(2, \omega_{\mathrm{i}+} \omega_{\mathrm{j}}\right)$ Where $\xi=$ damping ratio

$\omega_{\mathrm{i}}=$ modal frequency of the structure in one direction $\omega_{\mathrm{j}}=$ next modal frequency of the structure in same direction.

\subsubsection{Time History Analysis in SAP2000:}

The step by step procedure is as follows

i) The model representing the building structure is created and vertical loads (dead load and live load), member properties and member nonlinear behaviours are defined and assigned to the model

ii) Floor masses are assigned to the model.

iii) Hinge properties are defined and these properties are assigned to the member ends considering endoffsets.

iv) The ground motion record is defined as a function of acceleration versus time.

v) Defining a time history function by adding a function from file. In our case the Near source and Far source earthquake record has been linked to the program. 
vi) Defining a separate analysis case under the load type 'quake' with the appropriate analysis case type i.e Nonlinear direct integration time history.

vii) Applying earthquake acceleration values from the defined time history function.

viii) Specifying the damping coefficients by calculating the mass and stiffness proportional coefficients as per the equation mentioned above or inputting the frequency or time periods of two consecutive modes of the structure in the same direction whereby the programs itself calculates the required damping coefficients.

ix) Specifying a direct integration method in the program. In our case we have adopted Newmarks direct integration method.

$\mathrm{x}$ ) Running the analysis

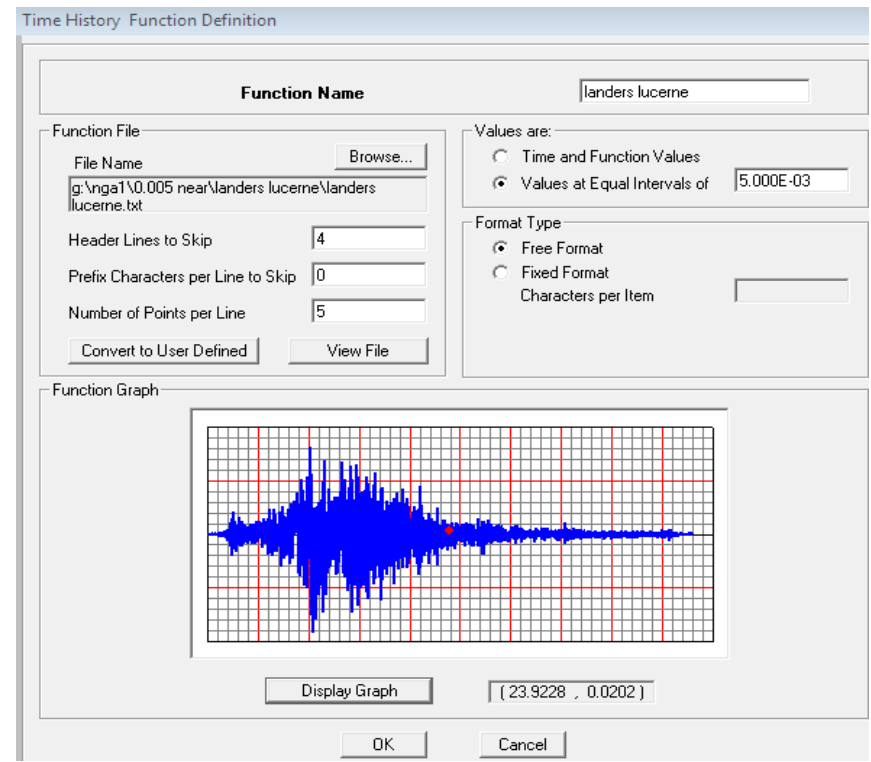

Fig-4 Defining Time History function for Near Source Earthquake (Lander, 1992) in SAP2000

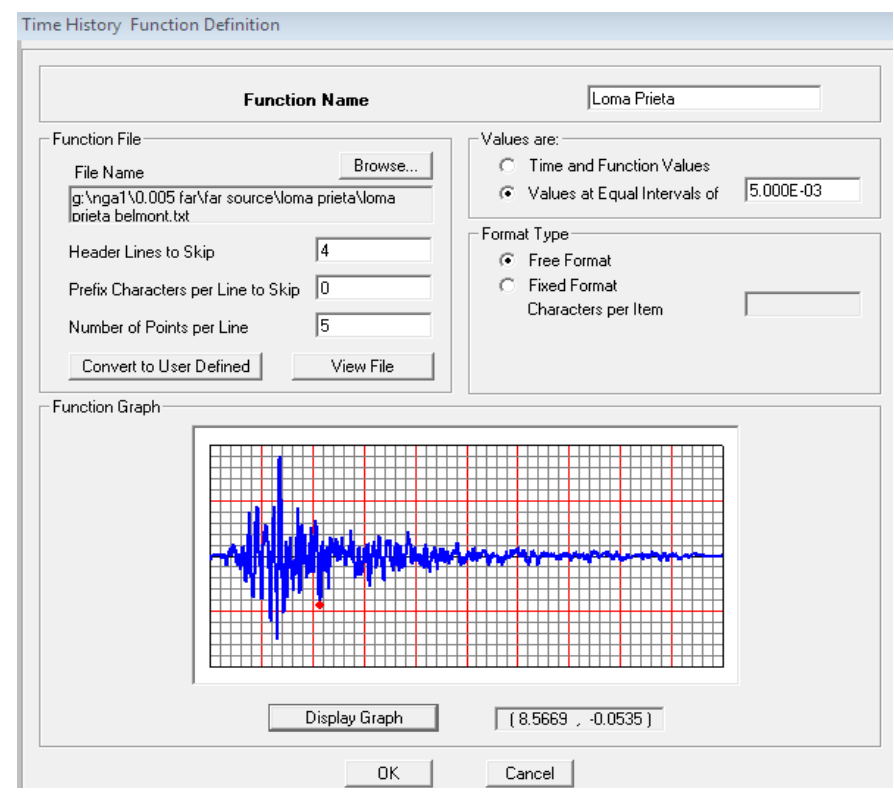

Fig-5 Defining time history function for Far Source Earthquake (Loma Prieta) in SAP2000

\section{RESULTS}

In order to study impact on adjacent structure response (lateral displacement, base shear and maximum pounding force), modelling was done for two cases using SAP2000 software. The buildings were separated by a distance equal to $10 \mathrm{~cm}$. Following were the results obtained.

\subsection{Case 1 - Impact of One Floor of Building with} Adjacent one for Floor to Floor pounding with same Height

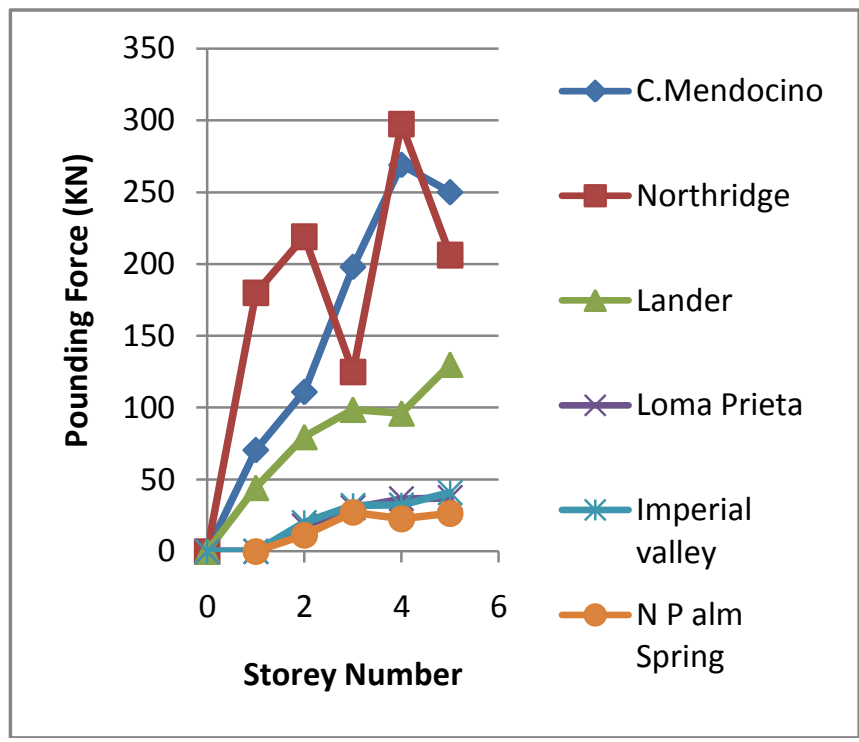

Fig-6 The Impact force in G+5A Storey building adjacent to G+5B Storey Building for Floor to Floor Pounding

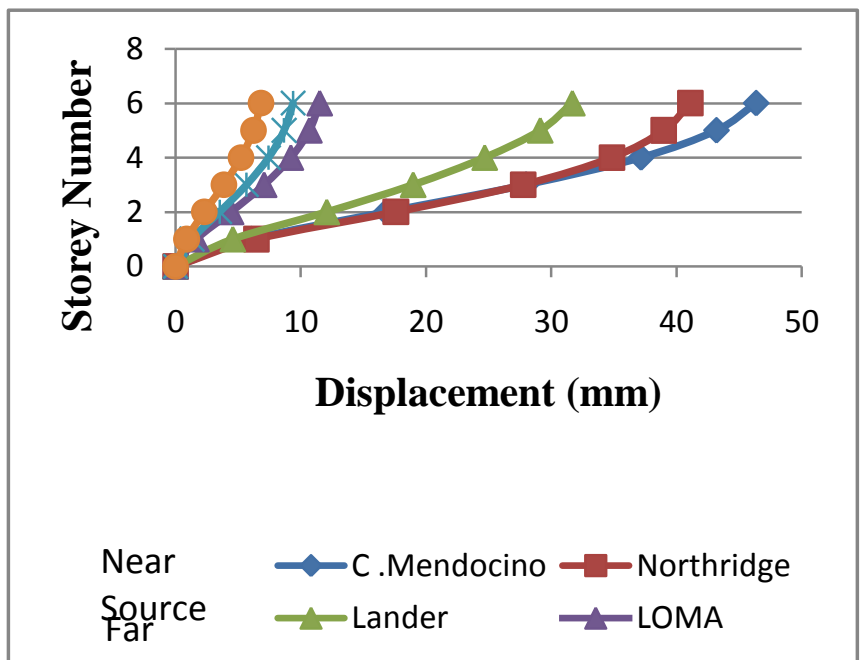

Fig-7 The Lateral Displacement of the G+5A Storey building due to adjacent G+5B Storey Building 


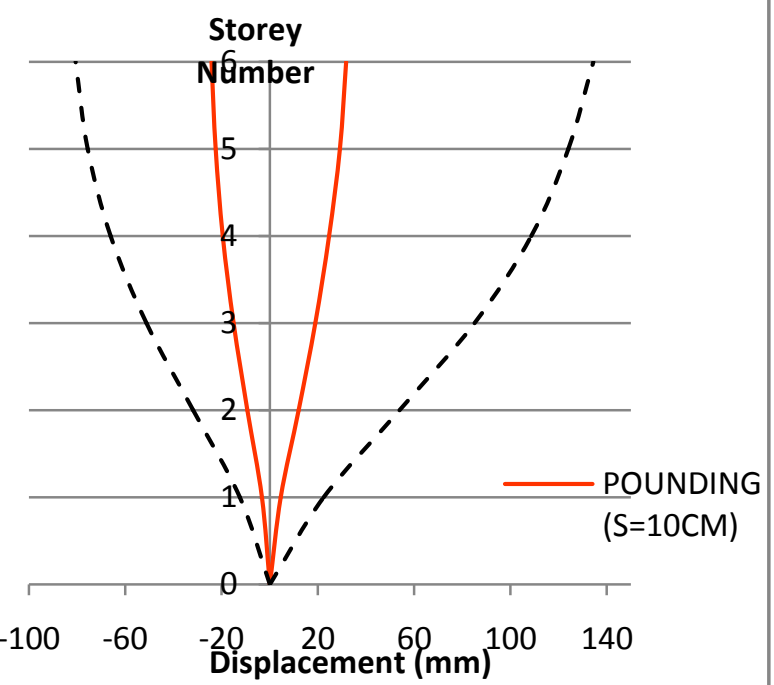

Fig-8 The lateral displacement of the G+5A story building under the Lander Accelerograph

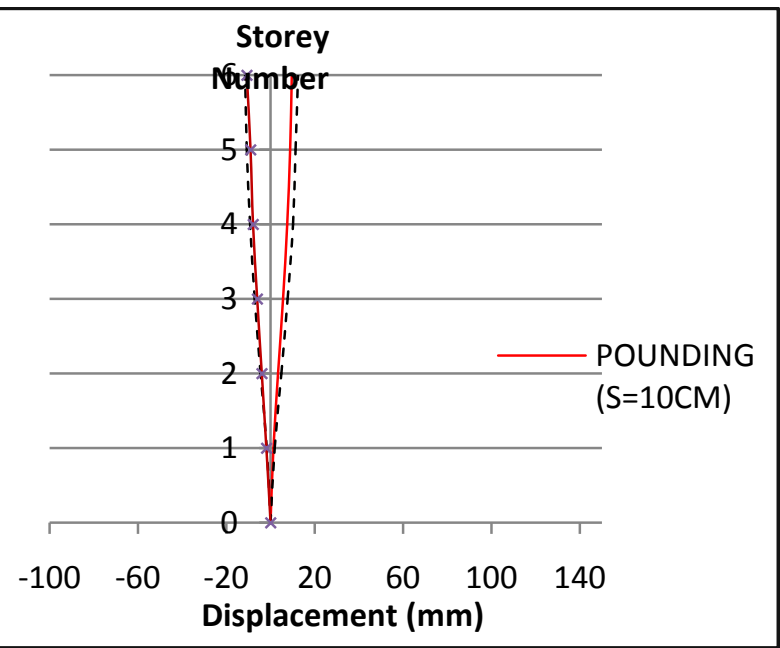

Fig-9 The lateral displacement of the G+5A story building under the Loma Prieta accelerograph

Results are tabulated as follows:

Table 5: Comparison of Response Parameters for floor to floor pounding with same height for Near Source Earthquakes

\begin{tabular}{|l|l|l|l|l|l|}
\hline \multicolumn{1}{|l}{$\begin{array}{l}\text { G+5A building adjacent to } \\
\text { Earthquakes }\end{array}$} \\
\hline \multirow{2}{*}{ Earthquake } & M.P.F & A.I.L & A.T.L & B.S & M.S.D \\
\cline { 2 - 6 } & $\mathrm{KN}$ & $\mathrm{m} / \mathrm{s}^{2}$ & $\mathrm{~m} / \mathrm{s}^{2}$ & $\mathrm{KN}$ & $\mathrm{mm}$ \\
\hline Northridge & 306.3 & 76.64 & 76.64 & 505.5 & 2.11 \\
\hline $\begin{array}{l}\text { Cape } \\
\text { Mendacino }\end{array}$ & 269.25 & 40.05 & 37.59 & 522.2 & 3.31 \\
\hline Landers & 129.954 & 32.49 & 64.74 & 446.2 & 2.578 \\
\hline
\end{tabular}

Table 6: Comparison of Response Parameters for floor to floor pounding with same height for Far Source Earthquakes

\begin{tabular}{|l|l|l|l|l|l|}
\hline $\begin{array}{l}\text { G+5A building adjacent to } \\
\text { Earthquakes }\end{array}$ & M.P.F & A.I.L & A.T.L & B.S & M.S.D \\
\hline \multirow{2}{*}{ Earthquake } & $\mathrm{KN}$ & $\mathrm{m} / \mathrm{s}^{2}$ & $\mathrm{~m} / \mathrm{s}^{2}$ & $\mathrm{KN}$ & $\mathrm{mm}$ \\
\hline Loma Prieta & 37.35 & 20.35 & 20.35 & 176.7 & 0.824 \\
\hline $\begin{array}{l}\text { Imperial } \\
\text { Valley }\end{array}$ & 40.928 & 10.54 & 15.2 & 130.5 & 0.709 \\
\hline N Palm Spring & 27.142 & 6.77 & 8.51 & 94.5 & 0.59 \\
\hline
\end{tabular}

Where,

M.P.F-Maximum Pounding Force

A.I.L-Acceleration at Impact Level

A.T.L-Acceleration at Top Level

B.S-Base Shear

M.S.D-Maximum storey Drift

In table $5 \& 6$, the maximum pounding force in the Near source earthquake were 65 to $92 \%$ higher than the maximum pounding force in the far source earthquake for all number of stories. Similarly, the acceleration at impact level in the Near source earthquake were 36 to $92 \%$ higher than the acceleration at impact level in the far source earthquake for all number of stories. Similarly, the acceleration at top level in the Near source earthquake were 40 to $90 \%$ higher than the acceleration at top level in the far source earthquake for all number of stories. Similarly, the base shear in the Near source earthquake were 60 to $82 \%$ higher than the base shearing the far source earthquake for all number of stories. Similarly, the Maximum storey drift in the Near source earthquake were 60 to $83 \%$ higher than the base shear in the far source earthquake for all number of stories.

\subsection{Case 2 - Impact of One Floor of Building with} Adjacent one for Floor to Floor pounding with

\section{different Height}

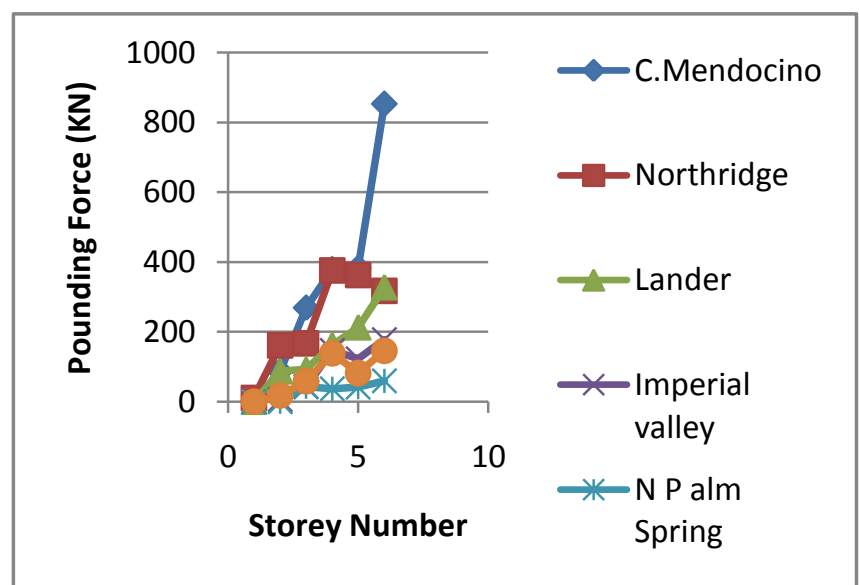

Fig-10 The Impact force in $\mathrm{G}+8$ Storey building due to adjacent G+5B Storey Building for Floor to Floor Pounding 


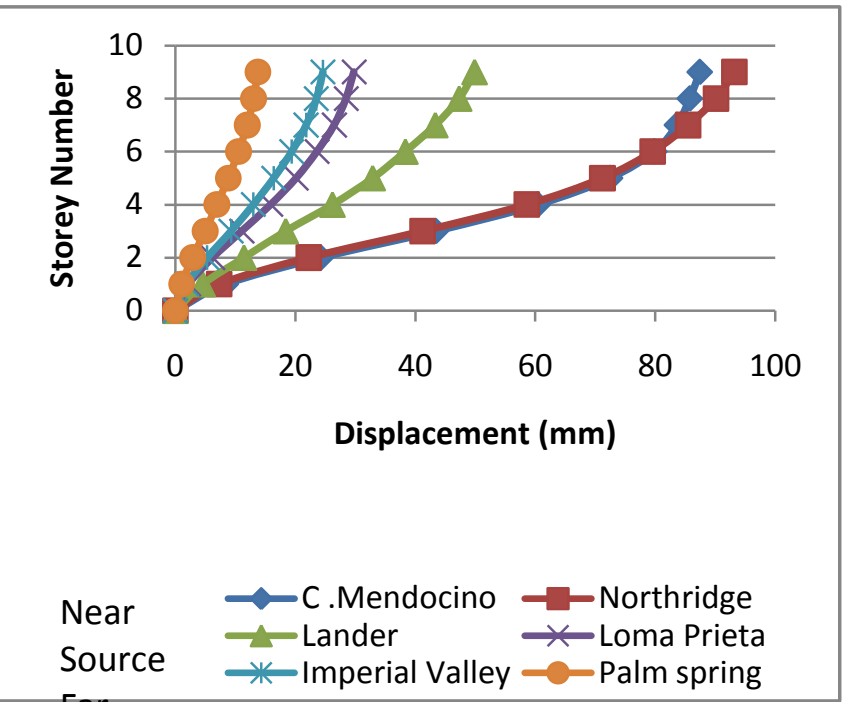

Fig-11 The Lateral Displacement of the G+8 Storey building due to adjacent G+5B Storey Building

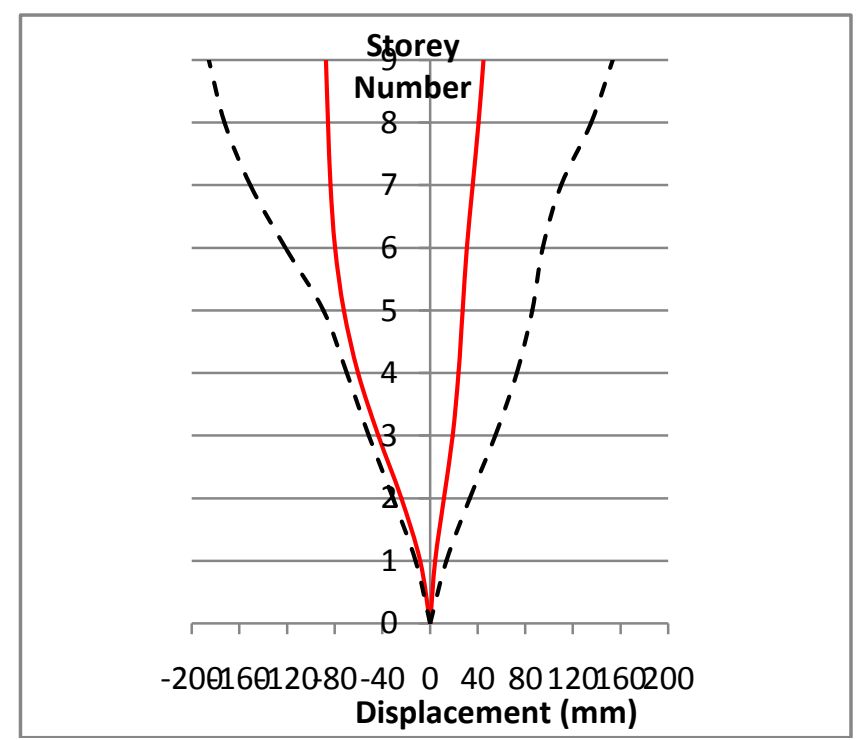

Fig-12 The lateral displacement of the $\mathrm{G}+8$ story building under the Cape Mendacino accelerograph

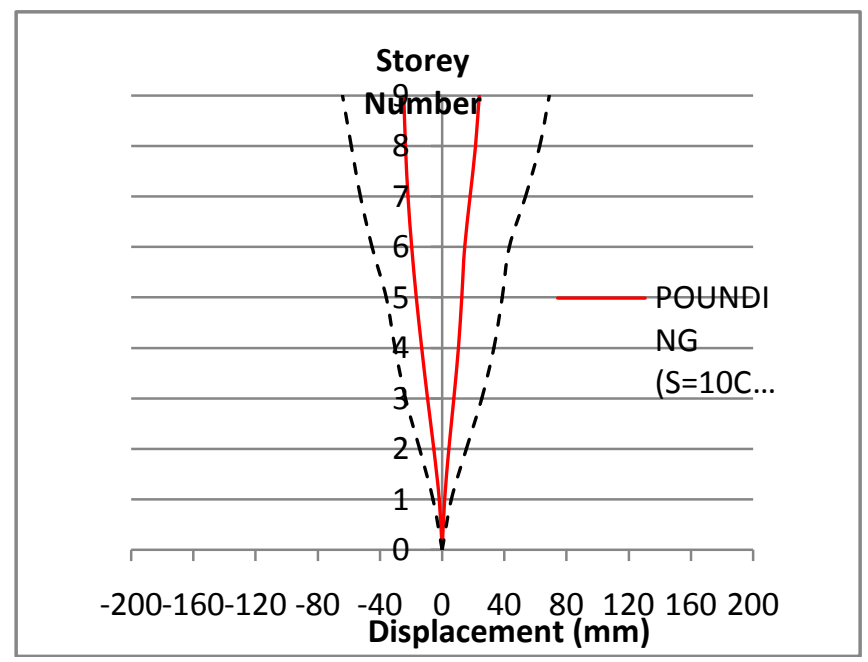

Fig-13 The lateral displacement of the G+8 story building under the Imperial Valley accelerograph
Results are tabulated as follows:

Table 7: Comparison of Response Parameters for floor to floor pounding with different height for Near Source Earthquakes

\begin{tabular}{|l|l|l|l|l|l|}
\hline $\begin{array}{l}\text { G+8 building adjacent to } \\
\text { Earthquakes }\end{array}$ & M.P.F & A.I.L & A.T.L & B.S & M.S.D \\
\hline \multirow{2}{*}{ Earthquake } & $\mathrm{KN}$ & $\mathrm{m} / \mathrm{s}^{2}$ & $\mathrm{~m} / \mathrm{s}^{2}$ & $\mathrm{KN}$ & $\mathrm{mm}$ \\
\cline { 2 - 6 } & 375.40 & 102.30 & 102.30 & 534.89 & 3.07 \\
\hline $\begin{array}{l}\text { Northridge } \\
\text { Mendacino }\end{array}$ & 853.00 & 44.78 & 100.29 & 520.30 & 1.66 \\
\hline Landers & 327.46 & 38.31 & 126.57 & 412.90 & 2.57 \\
\hline
\end{tabular}

Table 8: Comparison of Response Parameters for floor to floor pounding with different height for Far Source Earthquakes

G+8 building adjacent to G+5B for Far Source Earthquakes

\begin{tabular}{|l|l|l|l|l|l|}
\hline Earthquake & M.P.F & A.I.L & A.T.L & B.S & M.S.D \\
\cline { 2 - 6 } & $\mathrm{KN}$ & $\mathrm{m} / \mathrm{s}^{2}$ & $\mathrm{~m} / \mathrm{s}^{2}$ & $\mathrm{KN}$ & $\mathrm{mm}$ \\
\hline $\begin{array}{l}\text { Loma } \\
\text { Prieta }\end{array}$ & 146.23 & 26.71 & 91.22 & 222.54 & 1.30 \\
\hline $\begin{array}{l}\text { Imperial } \\
\text { Valley }\end{array}$ & 178.49 & 51.49 & 51.49 & 188.60 & 1.00 \\
\hline $\begin{array}{l}\mathrm{N} \text { Palm } \\
\text { Spring }\end{array}$ & 60.07 & 3.71 & 41.09 & 94.78 & 0.70 \\
\hline
\end{tabular}

Where,
M.P.F-Maximum Pounding Force
A.I.L-Acceleration at Impact Level
A.T.L-Acceleration at Top Level
B.S-Base Shear
M.S.D-Maximum storey Drift

In table $7 \& 8$, the maximum pounding force in the Near source earthquake were 45 to $92 \%$ higher than the maximum pounding force in the far source earthquake for all number of stories. Similarly, the acceleration at impact level in the Near source earthquake were 30 to $98 \%$ higher than the acceleration at impact level in the far source earthquake for all number of stories. Similarly, the acceleration at top level in the Near source earthquake were 10 to $70 \%$ higher than the acceleration at top level in the far source earthquake for all number of stories. Similarly, the base shear in the Near source earthquake were 45 to $83 \%$ higher than the base shear in the far source earthquake for all number of stories. Similarly, the Maximum storey drift in the Near source earthquake were 30 to $98 \%$ higher than the base shear in the far source earthquake for all number of stories. 
A Plot of Acceleration, Base shear and Pounding Force v./s Time for Floor to floor Pounding with same height for Cape Mendacino earthquake is shown below:
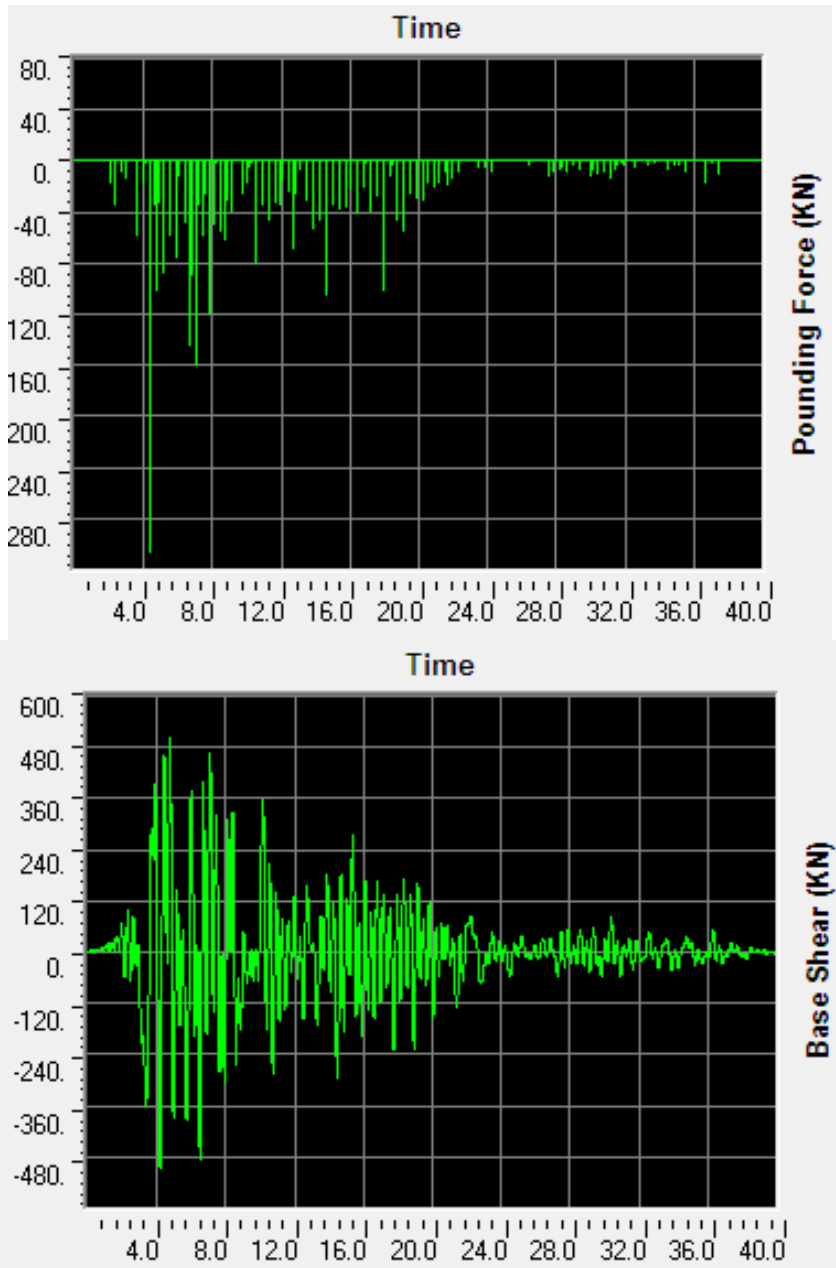

Time

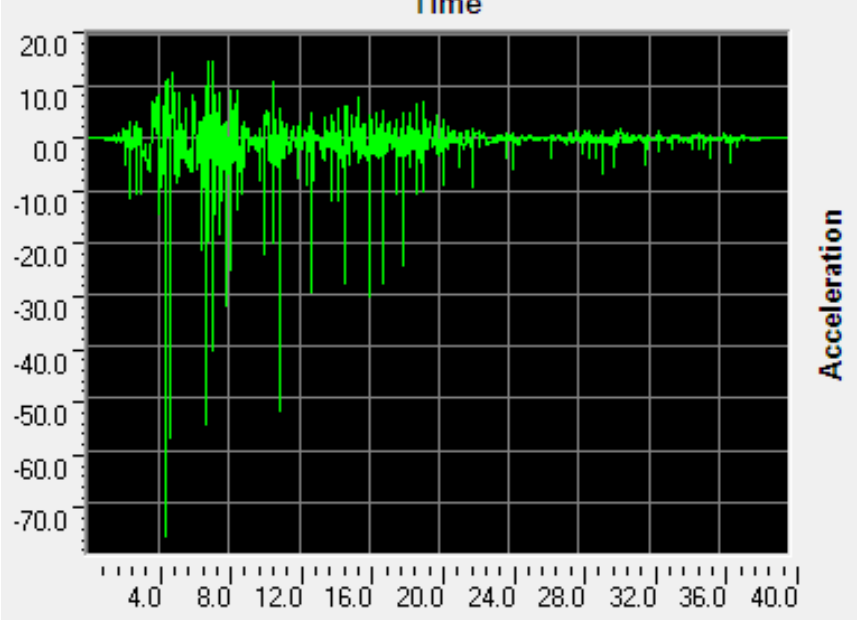

Fig-14 A Plot of Acceleration, Base shear and Pounding

Force v./s Time for Floor to floor Pounding with same height for Cape Mendacino earthquake

A Plot of Acceleration, Base shear and Pounding Force v/s Time for floor to floor Pounding with different height for Cape Mendacino earthquake is shown below:
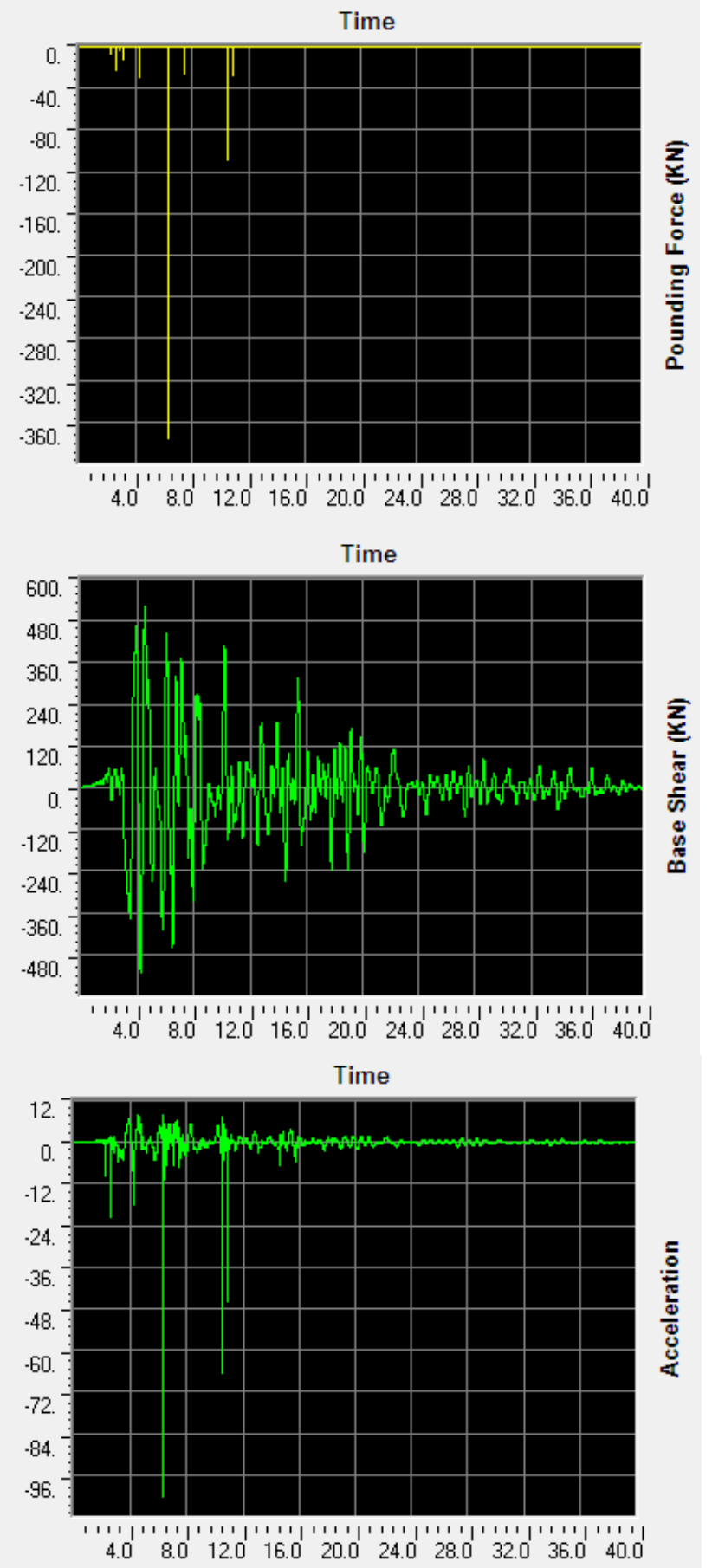

Fig-15 A Plot of Acceleration, Base shear and Pounding Force v/s Time for floor to floor Pounding with different height for Cape Mendacino earthquake

\subsection{Required Seismic Separation Distance to avoid} pounding for Maximum Displacement for Near

\section{Source and Far Source Earthquakes}

Assessment of the separation distance as per 2000 edition of the International building code (ICB) and in many seismic design codes and regulations worldwide, minimum separation distances as per a Absolute sum (ABS), Square Root of Sum of Squares (SRSS) and DDC (Double 
Difference Combination) for the above pounding models is as follows.

Table 9: $\mathrm{G}+5 \mathrm{~A}$ building adjacent to $\mathrm{G}+5 \mathrm{~B}$ For Floor to Floor Pounding with same height

\begin{tabular}{|c|c|c|c|c|c|c|c|}
\hline \multirow{3}{*}{$\begin{array}{l}\text { Inpu } \\
\text { t } \\
\text { Eart } \\
\text { hqua } \\
\text { ke }\end{array}$} & \multirow{3}{*}{$\begin{array}{l}\mathrm{Ua} \\
(\mathrm{m})\end{array}$} & \multirow{3}{*}{$\begin{array}{l}\mathrm{Ub} \\
(\mathrm{m})\end{array}$} & \multirow{3}{*}{$\begin{array}{l}\text { ABS } \\
S(m)\end{array}$} & \multirow{3}{*}{$\begin{array}{l}\text { SRSS } \\
\text { S (m) }\end{array}$} & \multicolumn{3}{|c|}{ DDC S } \\
\hline & & & & & $\mathrm{U}_{\mathrm{Rel}}$ & $\mathrm{U}_{\mathrm{Rel}} /$ & $\mathrm{U}_{\text {Rel }}$ \\
\hline & & & & & $\mathrm{S}(\mathrm{m})$ & $\begin{array}{l}\text { ua\&u } \\
\text { b) }\end{array}$ & Ub) \\
\hline $\begin{array}{l}\text { Nort } \\
\text { hrid } \\
\text { ge }\end{array}$ & 0.45 & $\begin{array}{l}0.3 \\
50\end{array}$ & 0.800 & 0.570 & 0.540 & 1.200 & 0.675 \\
\hline $\begin{array}{l}\text { Palm } \\
\text { Spri } \\
\text { ng }\end{array}$ & 0.04 & $\begin{array}{l}0.0 \\
27\end{array}$ & 0.067 & 0.048 & 0.045 & 1.125 & 0.671 \\
\hline
\end{tabular}

S-separation distance

Table 10: $\mathrm{G}+8$ building adjacent to $\mathrm{G}+5 \mathrm{~B}$ for Floor to Floor pounding with different height

\begin{tabular}{|c|c|c|c|c|c|c|c|}
\hline \multirow{2}{*}{$\begin{array}{l}\text { Input } \\
\text { Earthq } \\
\text { uake }\end{array}$} & \multirow{2}{*}{$\begin{array}{l}\text { Ua } \\
(\mathrm{m} \\
)\end{array}$} & \multirow{2}{*}{$\begin{array}{l}\text { Ub } \\
(\mathrm{m} \\
)\end{array}$} & \multirow{2}{*}{$\begin{array}{l}\text { AB } \\
\text { S S } \\
(m\end{array}$} & \multirow{2}{*}{$\begin{array}{l}\text { SR } \\
\text { SS } \\
\text { S } \\
(\mathrm{m})\end{array}$} & \multicolumn{3}{|c|}{ DDC S } \\
\hline & & & & & $\begin{array}{l}\begin{array}{l}\mathrm{U}_{\mathrm{R}} \\
\mathrm{el}\end{array} \\
\mathrm{S}( \\
\mathrm{m})\end{array}$ & $\begin{array}{l}\mathrm{U}_{\mathrm{Rel}} / \max ( \\
\mathrm{ua} \& \mathrm{ub})\end{array}$ & $\begin{array}{l}\mathrm{U}_{\mathrm{Rel}} \\
/(\mathrm{Ua}+ \\
\mathrm{Ub})\end{array}$ \\
\hline $\begin{array}{l}\text { Northr } \\
\text { idge }\end{array}$ & $\begin{array}{l}0.5 \\
09\end{array}$ & $\begin{array}{l}0.3 \\
50\end{array}$ & $\begin{array}{l}0.8 \\
59\end{array}$ & $\begin{array}{l}0.6 \\
18\end{array}$ & $\begin{array}{l}0.5 \\
86\end{array}$ & 1.151 & 0.682 \\
\hline $\begin{array}{l}\text { Imperi } \\
\text { al } \\
\text { Valley }\end{array}$ & $\begin{array}{l}0.0 \\
69\end{array}$ & $\begin{array}{l}0.0 \\
35\end{array}$ & $\begin{array}{l}0.1 \\
04\end{array}$ & $\begin{array}{l}0.0 \\
77\end{array}$ & $\begin{array}{l}0.0 \\
74\end{array}$ & 1.072 & 0.711 \\
\hline
\end{tabular}

The maximum displacements for all the cases Ua \& Ub and the relative pounding displacement $U_{\text {Rel }}$ for different excited are listed in Table .Since the Double Diffference Combination (DDC) approach assumes complete out of phase motion of the adjacent buildings, so the ratio of $U_{\text {Rel }}$ to the sum of $\mathrm{Ua}$ and $\mathrm{Ub}$ could be taken as out phase of adjacent buildings, which range from 0.67 to 0.71 depending upon the input earthquake characteristic. The out of phase movement is clearly observed due to different periods of building. Therefore seismic pounding between adjacent buildings may induce unwanted damages even though individual structure might have been designed properly to withstand the strike of credible earthquake events.

\section{CONCLUSIONS}

In this study a mathematical modeling of adjacent building pounding has been demonstrated and its implementation in a finite element nonlinear seismic analysis is presented.In view of the results obtained by the nonlinear time history analyses of the considered building structures, following primary conclusions on the prediction of the nonlinear behaviour of the models are obtained:

i) The displacement for near-source ground motion is much larger than those of far source ground motion. Hence the pounding possibility during near-source ground motion is much larger than during far-source ground motion with same gap. ii) Seismic gap required under near-source ground motion is 35 to $70 \%$ higher than far-source ground motion.

iii) It is clear that adjacent building with same height and matching stories will show similar behavior and pounding damage will be limited to nonstructural components.

iv) Separation between the adjacent structures needs to be considered to achieve optimal design with passive energy dissipation, i.e by increasing the gap width to mitigate the damage of building adjacent to each other as given in codes.

v) The maximum response (lateral displacement and maximum impact) caused by the impact of two adjacent buildings, decreases in the shorter building, whereas it increases in the taller one, which may lead to critical conditions.

\section{REFERNCES}

[1] Robert L. Wiegel, "Earthquake Engineering", Prentice-Hall,Inc., Englewood Cliffs, N.J , Tenth Edition.

[2] Pankaj Agarwal and Manish Shrikhande, "Earthquake Resistant Design of Structures"2009 Edition.

[3] Bruce F. Maison and Kazuhiko Kasai, "Analysis for Type of Structural Pounding", ASCE, Journal of Structural Engg. Vol. 116, No. 4, p.p 957-977

[4] Diego Lopez Garcia, "Probabilistic Evaluation of the Separation Distance Between Adjacent Systems" Department of Civil, Structural \& Environmental Engineering, University of Buffalo.

[5] Jeng-Hsiang Lin and Cheng-Chiang Weng, "Probability Analysis of Seismic Pounding of Adjacent Buildings", Earthquake Engg. Structural and Dynamics 2001; 30:1539-1557 (DOI: 10.1002/eqe.78

[6] Gary R. Searer and Sigmund A. Freeman, "Design Drift Requirement for Long Period Structures", Thirteenth World Conference on Earthquake Engineering Vancouver B.C., Canada August 1-6, 2004 Paper No. 3292.

[7] Austin Brown and M. Saiid Saiidi, "Investigation of Near-Fault vs. Far field ground Motion Effect on a Substandard Bridge Bent", University of Nevada, Reno.

\section{BIOGRAPHIES}

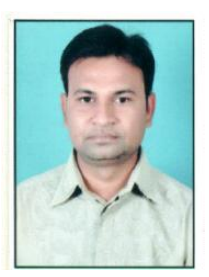

Chetan J. Chitte obtained his M.Tech. in Structural Dynamics \& Earthquake Engineering from VNIT, Nagpur and B.E. Civil from Sardar Patel College of Engineering, Mumbai. He has 4.5 Years experience in Structural Designing and 3 Years experience in area of teaching. 


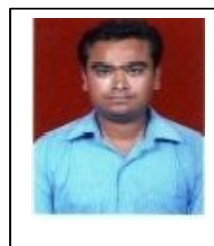

Anand S. Jadhav obtained his M.E. in Civil Strutures from Govt. COE, Karad \& B.E. Civil from KKECOE, Nashik. He has 3.0 Years experience in area of teaching \& 1 Year in industry.

Hemraj R. Kumavat obtained his M. E. in Building Science \& Technology \& B.E. Civil from North Maharashtra University. He has 8.5 Years experience in area of teaching. 